\title{
Escolarização, profissionalização e desenvolvimento em escola do campo: o caso de egressos da CEPE na Ilha de Cotijuba, Belém, Pará
}

\author{
José Bittencourt da Silva ${ }^{1}$ \\ ${ }^{1}$ Universidade Federal do Pará - UFPA. Núcleo de Estudos Transdisciplinares em Educação Básica. Rua Augusto Corrêa, \\ Número 1, Guamá. Belém-PA. Brasil. \\ Autor para correspondência/Author for correspondence: josebittencourtsilva@gmail.com
}

\begin{abstract}
RESUMO. O presente artigo objetiva analisar o desenvolvimento socioeconômico e educacional de egressos escolarizados na Casa Escola da Pesca (CEPE), uma escola pública municipal do campo, em regime de tempo integral na modalidade EJA, com habilitação profissional técnica na área da pesca, correspondente aos níveis de ensino fundamental e médio. Tomou-se como referência empírica a atual realidade vivida por ex-alunos moradores da ilha de Cotijuba, Belém, Pará que concluíram a formação básica no ano de 2015. Metodologicamente, o trabalho baseia-se em pesquisa qualitativa de campo, com recolhimento de documentos, aplicação de questionários, realização de entrevistas e observações in loco. Conclui-se que as condições materiais objetivas dos sujeitos da pesquisa, associada à ausência de ralações cotidianas em contextos organizativos condicionam negativamente o desenvolvimento socioeconômico e educacional dos egressos da CEPE o que pressuporia que a escola tivesse o associativismo como princípio educativo.
\end{abstract}

Palavras-chave: Casa Escola da Pesca, Escola do Campo, Desenvolvimento, Egressos. 


\title{
Schooling, professionalism and development in the rural school: the case of ex-students from the CEPE in the Island of Cotijuba, Belém, Pará
}

\begin{abstract}
The objective of this article is to analyze the socioeconomic and educational development of students enrolled in the House School of Fisheries (CEPE), a full-time municipal public rural school in the EJA modality, with professional qualification in the fishing area, corresponding to Elementary School and High School levels. The current reality of ex-students living on the island of Cotijuba, Belem, Para, who completed basic training in the year 2015, was taken as an empirical reference. Methodologically, this work is based on qualitative field research, with collection of documents, application of questionnaires, interviews and local observations. It's concluded that the material conditions of the interviewees, coupled with the absence of day by day relations in organizational contexts, negatively affect the socioeconomic and educational development of the CEPE graduates, which would imply that the school had the associativism as an educational principle.
\end{abstract}

Keywords: House School of Fisheries, Rural School, Development, Ex-Students. 


\section{Escolarización, profesionalización y desarrollo en escuela del campo: el caso de egresos de la CEPE en la Isla de Cotijuba, Belém, Pará}

RESUMEN. El presente artículo tiene como objetivo analizar el desarrollo socioeconómico y educativo de egresados escolarizados en la Casa Escuela de la Pesca (CEPE), una escuela pública municipal del campo, en régimen de tiempo completo en la modalidad Educación de Jóvenes y Adultos, con habilitación profesional técnica en el área de la pesca, correspondiente a los niveles de enseñanza fundamental y media. Se tomó como referencia empírica la actual realidad vivida por ex alumnos de la isla de Cotijuba, Belém, Pará que concluyeran la formación básica en el año 2015. Metodológicamente, el trabajo está embasado en investigación cualitativa de campo, con investigación documental, aplicación de cuestionarios, realización de entrevistas y observaciones in situ. Se concluye que las condiciones materiales objetivas de los sujetos de la investigación, asociada a la ausencia de relaciones cotidianas en contextos organizativos condicionan negativamente el desarrollo socioeconómico y educativo de los egresados de la CEPE, es esta eduque con base en el asociativismo como principio educativo.

Palabras clave: Casa Escuela de Pesca, Escuela del Campo, Desarrollo, Egresos. 


\section{Introdução}

A Casa Escola da Pesca (CEPE) é uma escola pública municipal de tempo integral na modalidade Educação de Jovens e Adultos (EJA), correspondente aos níveis de ensino fundamental e médio. Está localizada em Outeiro, área insular do município de Belém do Pará, com uma proposta integradora dos processos de escolarização básica com a profissionalização de seus/suas discentes. De acordo com o Projeto Político Pedagógico (Belém, 2017) e sua Portaria de criação (Funbosque, 2010), a CEPE está voltada para a formação de filhos/as de pescadores/as e trabalhadores/as da pesca na região das ilhas de Belém. Sua finalidade maior é contribuir com o desenvolvimento local, reduzindo a pobreza e melhorando as relações comunitárias ribeirinhas com o meio ambiente.

Do ponto de vista pedagógico, a Escola se propõe a trabalhar os conteúdos de maneira interdisciplinar, utilizando a Pedagogia da Alternância como método de ensino. Neste contexto, o trabalho é colocado como um princípio educativo estruturante das relações entre professor e aluno, a partir de eixos temáticos e da pedagogia de projetos, tudo transversalizado pela Educação Ambiental. A ideia é a de que a CEPE consiga implementar uma escolarização respeitando dois tempos formativos distintos a saber: os/as discentes passam quinze (15) dias estudando os conteúdos escolares/profissionalizantes em regime de internato (tempo escola) e quinze (15) dias em seus espaços de convívio familiar e comunitário (tempo comunidade), buscando colocar em prática as vivências, experiências e práticas do tempo escola.

Objetiva-se neste artigo expor e analisar a questão do desenvolvimento socioeconômico e educacional de egressos da CEPE a partir da realidade de ex-alunos residentes na ilha de Cotijuba, afinal a escola se propõe a contribuir para a formação de "sujeitos empreendedores, ecológicos e multiplicadores de informações e tecnologias, bem como atuantes como profissionais técnicos em recursos pesqueiros" (Belém, 2013, p. 18). Neste sentido, têm-se alguns questionamentos acerca desta realidade, a saber: a CEPE e seu atual processo formativo tem se constituído em um meio relevante para o desenvolvimento de seus egressos e do local onde moram ou ela está apenas certificando jovens e adultos que procuram escolas na modalidade EJA? A CEPE tem contribuído ao desenvolvimento das condições sociais, econômicas, culturais e ambientais de seus egressos? 
Além desta introdução, da conclusão e das referências, o trabalho está estruturado da seguinte maneira: Primeiro tem-se uma breve discussão teórica sobre o conceito de desenvolvimento numa perspectiva crítica; posteriormente, apresentam-se os materiais e o método da pesquisa; em seguida apresenta-se uma caracterização da CEPE, enfocando seus aspectos históricos, geográficos e legais que deram a esta escola existencial formal enquanto estabelecimento de ensino. Em seguida, tem-se uma apresentação de aspectos administrativos e pedagógicos da escola, em que se pretendeu expor brevemente o modo como a CEPE se constitui do ponto de vista da gestão e das práticas pedagógicas, com especial destaque para a proposta da alternância pedagógica. Ao final, fez-se uma exposição empírica e analítica da atual realidade de egressos da escola, com enfoque prioritário naqueles moradores da ilha de Cotijuba.

\section{Desenvolvimento: o que é isso?}

Todo conceito apresenta certa processualidade sócio-histórica e, portanto, filia-se a uma perspectiva ideológica. $\mathrm{O}$ conceito de desenvolvimento (e sua versão atual de desenvolvimento sustentável) é emblemático neste sentido. Em muitos dicionários on line da língua portuguesa
(Dicionários, 2018; Dicionário, 2018), a palavra desenvolvimento aparece como sinônimo de desenvolver, acrescentar ou de melhorar/aperfeiçoar algo em uma pessoa, uma família, comunidade, região ou país. O conceito pode ser relacionado também a processos tecnológicos e econômicos e, neste caso, assemelha-se à ideia de crescimento. Pode-se então dizer que a palavra desenvolvimento nega o movimento de introspecção, pretendendo reverter uma possível realidade reprimida, oprimida, acanhada em uma ação de expansão, em um movimento de reação para fora.

Segundo Silva (2009) a ideia de desenvolvimento como progresso econômico tomou força a partir de meados do século passado, ou mais precisamente a partir do fim da Segunda Guerra Mundial em 1945. Foi neste contexto que parte dos países do ocidente europeu e, mormente os Estados Unidos da América, passaram a disseminar um conjunto de pensamentos teóricos e ideológicos objetivando incluir os chamados países subdesenvolvidos nos padrões de industrialização e consumo alcançados pelas nações capitalistas centrais. $\mathrm{O}$ desenvolvimentismo, como ficou conhecido, apontava para os fatores econômicos como o fundamento essencial para a melhoria da vida coletiva e, a 
indústria, seria a "locomotiva" de todo esse processo.

Destarte, desenvolver um dado território seria a mesma coisa que fazer crescer a sua capacidade produtiva industrial, aumentar o consumo da população, gerar emprego e renda. Por isso os governos dos países periféricos nas décadas de 1960/70 promoveram políticas públicas voltadas ao crescimento do produto interno bruto e ao aumento da renda per capita ${ }^{1}$ da população. Desenvolver, afirmava Furtado (1961, p. 115-116), era “ ... basicamente, aumento do fluxo de renda real, isto é, incremento na quantidade de bens e serviços por unidade de tempo à disposição de determinada coletividade". Após esse incremento na produção os outros benefícios (melhorias socioculturais) apareceriam quase que "naturalmente".

De fato, os ideólogos do desenvolvimentismo Pós-Segunda Guerra Mundial acreditavam piamente que possuíam a "formula mágica" para o bem estar social em todos os países. A chave para isso estava na economia (progresso técnico, aumento da capacidade do trabalho humano para explorar a natureza, maior produção de bens e serviços, etc.) (Porto-Gonçalves, 2012). O crescimento geraria, como que automaticamente, transformações positivas nas áreas da saúde, educação, habitação, transporte, alimentação, lazer, dentre outras. O crescimento (tecnológico e industrial) aparece, portanto, como início, meio e fim para a solução dos problemas sociais e humanos em um determinado território.

Em linhas gerais pode-se então dizer que o desenvolvimento nesta perspectiva seria a mesma coisa que processo de crescimento, cuja maturidade se dá ao atingir a capacidade industrial de crescer sem limites, de maneira continuada, constante e sustentada. Em nome desse ideário desenvolvimentista, valores mercadológicos são levados às últimas consequências e vão penetrando os mais variados campos sociais. Singer (2004) denomina esse modelo de "desenvolvimento capitalista", o qual se realiza determinado pela lógica do capital, do mercado, da competição, do individualismo e de um Estado mínimo.

Com o passar do tempo observou-se que o desenvolvimentismo fez crescer a riqueza material das nações, mas concentrou renda, aumentou a pobreza, recrudesceram as mazelas sociais nos países periféricos e impactou ferozmente os processos naturais em escala macro e micro. Neste contexto, a maior crítica feita ao discurso do desenvolvimento capitalista foi realizada na própria Europa pelos ambientalistas locais nas décadas de 
1960/70. De fato, as contradições internas entre o crescimento econômico e manutenção dos ecossistemas naturais geraram uma das mais contundentes críticas ao estado de coisas vigentes.

O modelo de produção e consumo ocidental capitalista, baseado no crescimento econômico infinito, agora é posto em cheque do ponto de vista de sua perdurabilidade material. Começa a ser colocada a ideia dos limites do crescimento: o planeta não é infinito e seus recursos não são infindáveis. $\mathrm{O}$ esgotamento dos recursos e a entropia gerada pelo modo industrial de apropriação da natureza se traduzem em poluição e deterioração da qualidade ambiental. (Silva, 2012, p. 206).

Ignacy Sachs, com sua proposta do ecodesenvolvimento, vai levantar questões globais que impedem a melhoria de vida imposta pelo desenvolvimento capitalista, o qual se impõe aos países do sul e atenta contra a própria natureza. Sachs (1986) vai mostrar que a economia baseada no capital é a fonte geradora dos atuais problemas socioambientais, pois aumenta a alienação, promove o individualismo, sufoca a participação e a democracia impossibilitando a emergia de modelos econômicos mais autossuficientes. Esse ideário do ecodesenvolvimento foi substituído pelo protagonismo da Organização das Nações Unidas (ONU) que mundializou o conceito de desenvolvimento sustentável como sendo aquele que satisfaz as necessidades atuais, sem comprometer a capacidade das futuras gerações satisfazerem as suas próprias necessidades (CMMAD, 1988).

Como se pode observar, o conceito de desenvolvimento e de desenvolvimento sustentável foi apropriado pelas grandes organizações e empresas capitalistas, tornando-o uma ideologia que sustenta os processos de saqueamento das riquezas naturais de países periféricos como Brasil, bem como a proletarização dos trabalhadores locais e desestruturação das comunidades e populações tradicionais.

Mas esta ideologia do
desenvolvimento sustentável fica
disfarçada mediante um potente
discurso de 'Proteção à Natureza',
com a aparência de 'bula para
salvação do mundo', que confere
uma ilusão de um discurso menos
agressor para com o domínio do
homem para com a natureza. Ao
absorver inclusive as classes
dominadas, a ideologia do
desenvolvimento sustentável
configura-se como um mecanismo de
dominação. Com esta plataforma
bem alicerçada, hoje, dificilmente se
permanece imune aos seus reflexos.
A ideologia atinge o seu grande
objetivo quando se torna,
indubitavelmente, senso comum.
(Oliveira, 2005, p. 45).

O ideário do desenvolvimento sustentável pode ser considerado como a terceira versão da ideologia do progresso, a mais atual ideologia legitimadora do desenvolvimento capitalista. 
Trata-se de explorar, de atribuir valor, de tirar proveito dos recursos naturais e humanos. Qualquer que seja o adjetivo que se lhe acrescente, o conteúdo implícito ou explícito do desenvolvimento é o crescimento econômico, o acúmulo de capital, com todos os efeitos positivos $\mathrm{e}$ negativos que conhecemos: competição impiedosa, aumento ilimitado das desigualdades, saque incontrolável da natureza. $\mathrm{O}$ fato de se acrescentar o adjetivo 'duradouro' ou 'sustentável' só confunde um pouco mais as coisas. Justamente hoje está circulando um manifesto pelo desenvolvimento sustentável, assinado por numerosas celebridades, entre as quais Jean-Claude Camdessus, ex-presidente do FMI. (Latouche, 2009, p. 17).

Por isso, os ideólogos do desenvolvimento sustentável pregam a economia verde, o consumo verde, desenvolvimento limpo e a ecoeficiência produtiva (Layrargues \& Lima, 2014). Todas essas nomenclaturas são colocadas como novidades e objetivos/metas a serem alcançados pelos indivíduos, famílias, poderes públicos etc. em cidades e países do planeta terra. Esse discurso é repetido tantas vezes quantas forem necessárias para que se torne senso comum e, assim, cumpra com sua função legitimadora do crescimento e apropriação de riquezas até que sejam explícitos os defeitos e contradições dessa nova/velha ideologia do progresso.

Para efeito analítico neste texto, partir-se-á da percepção conceitual de Singer (2004) que diferencia o desenvolvimento capitalista do solidário. Para este autor, as discussões teóricas sobre o desenvolvimento precisam levar em consideração a importância dada ou à competição ou à cooperação como motivadores dos comportamentos entendidos como os mais apropriados. O desenvolvimento capitalista prima

... pelos valores do livre funcionamento dos mercados, das virtudes de competição, do individualismo e do Estado mínimo. $\mathrm{O}$ desenvolvimento solidário é o desenvolvimento realizado por comunidades de pequenas firmas associadas ou de cooperativas de trabalhadores, federadas em complexos, guiado pelos valores da cooperação e ajuda mútua entre pessoas ou firmas, mesmo quando competem entre si nos mesmos mercados. (Singer, 2004, p. 9).

O desenvolvimento local que será conceitualmente aceito neste texto é aquele baseado em pequenos empreendimentos individuais, familiares ou coletivos que apresentam uma racionalidade ribeirinha (Silva; Santos \& Souza, 2016; Silva, 2009) e que não visam apenas, nem principalmente aos lucros. Precisamente, o conceito de desenvolvimento dos egressos da CEPE, de suas famílias e comunidades levará em consideração o fortalecimento e o uso das forças produtivas peculiares à pesca artesanal, o aumento de valores que fortaleçam os laços de confiança e solidariedade, o favorecimento da 
autorrealização e a melhoria dos aspectos educacionais, científicos e tecnológicos dos ex-alunos locais.

\section{Materiais e método}

Segundo Pires (2010), no âmbito das pesquisas qualitativas uma amostra pode ser entendida como parte determinada da realidade objetiva, a qual servirá de base empírica para as análises vinculadas aos objetivos e questões levantados previamente. É o resultado de qualquer operação visando constituir o corpus empírico de uma pesquisa, este entendido como o recorte arbitrário de elementos do real que o pesquisador define para que, ao aplicar sobre eles uma metodologia, possa atingir os objetivos traçados.

Nesta perspectiva, foi selecionada como amostra, a ilha de Cotijuba, a qual forneceu o corpus empírico desta pesquisa, materializado nas falas dos sujeitos educacionais egressos da CEPE, nos documentos sobre os processos escolares e nas situações cotidianas do real percebido, passíveis de serem registradas em caderno de campo, formulários de pesquisa, em aparelhos de gravação de voz e em máquinas fotográficas. Esses dados ajudaram na compreensão e análise das mediações e determinações subjacentes à expressão fenomênica do objeto (Kosik, 1976). Esse material foi imprescindível à construção crítica da totalidade (generalização teórica) enquanto unidade da diversidade ou concreto pensado. “... síntese de muitas determinações, isto é, unidade do diverso". (Marx, 2008, p. 258).

Para a consecução do objetivo traçado, assim como para as possíveis respostas às questões levantadas, tomou-se como referência dados qualitativos (entrevistas e observações) de uma pesquisa de campo realizada durante os meses de janeiro, fevereiro e março de 2018 junto a egressos formados em dezembro de 2015 pela CEPE, os quais são moradores da ilha de Cotijuba, Belém, Pará, Amazônia, Brasil, (Figura 1, a seguir). Esta investigação faz parte do projeto de pesquisa intitulado "Inovação escolar e escolas municipais de tempo integral em Belém do Pará: um estudo nas ilhas Mosqueiro e Caratateua". (Silva, 2018). 
Figura 1: Município de Belém e localização da pesquisa de campo com egressos da CEPE.

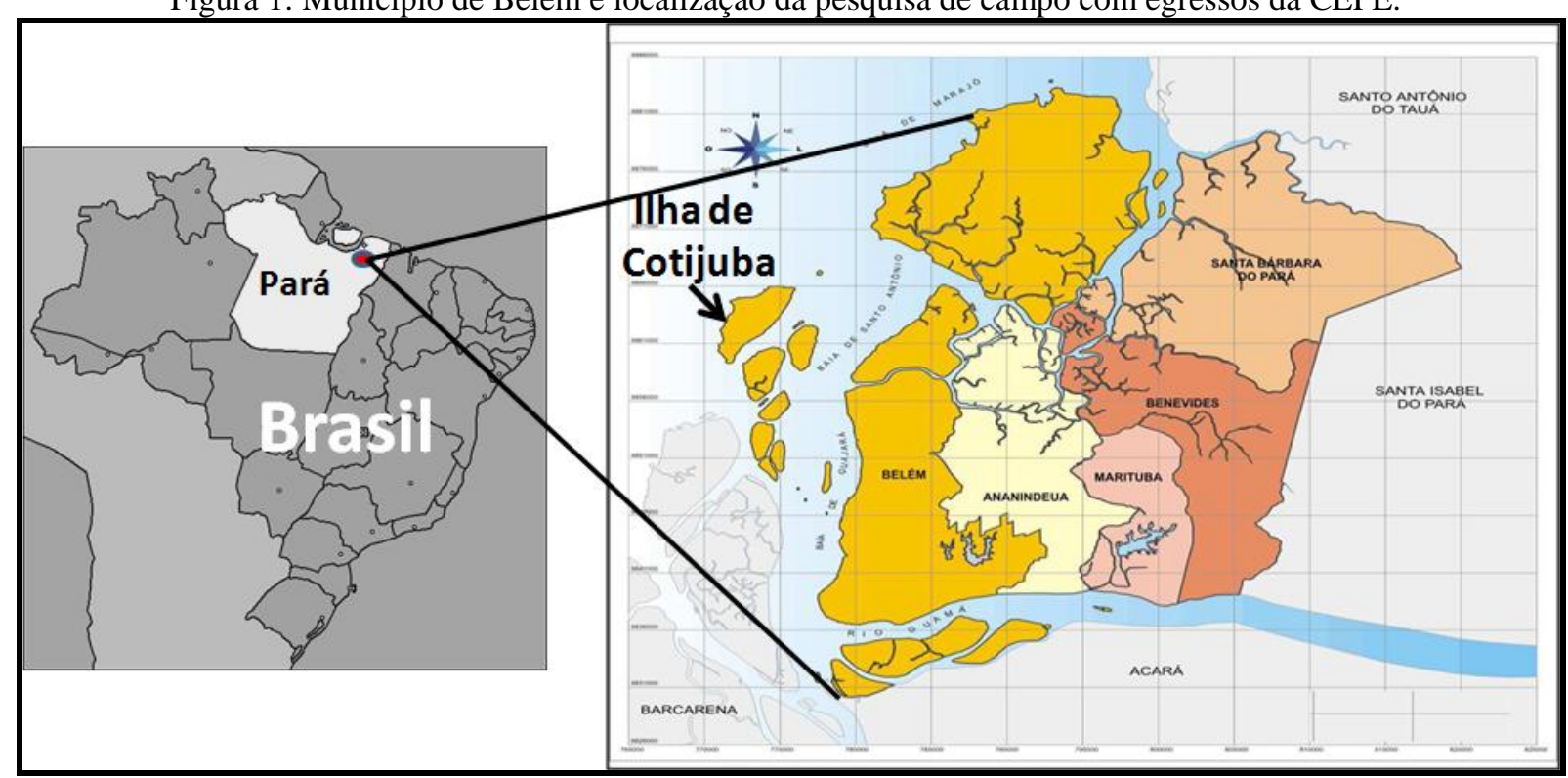

Fonte: Construído pelo autor a partir de Silva, Santos e Souza (2016).

Em Cotijuba foram aplicados seis (06) questionários com 12 perguntas fechadas e abertas que objetivaram recolher informações referentes às práticas laborais dos egressos, suas condições educacionais atuais e alguns aspectos ligados à questão da organização social ou econômica local. No final, o questionário apresentou uma indagação deu o mote para uma entrevista individual que abordou os sonhos e os desejos dos seis (06) egressos da CEPE que concluíram o ensino fundamental e médio nesta escola.

Esses discentes foram selecionados porque possuem uma trajetória formativa longa, ou seja, passaram quatro (4) anos ou mais na CEPE para a conclusão do ensino fundamental e o médio. Precisamente, são alunos que possuem as duas certificações, uma em nível fundamental com certificação em Pesca e Aquicultura e a outra em nível médio, com habilitação Técnica em Recursos Pesqueiros.

O material coletado foi analisado com base nas ideias de Singer (2004) e sua proposição dicotômica entre desenvolvimento capitalista e o desenvolvimento solidário. Desta maneira, considerou-se o desenvolvimento dos egressos (e famílias) a partir de melhoria das condições de trabalho, do uso das forças produtivas peculiares à pesca artesanal, ao fortalecimento da capacidade organizativa dos egressos, ao aumento de valores coletivos que incrementam os laços de confiança e solidariedade da categoria, o favorecimento da 
autorrealização e a melhoria dos aspectos educacionais, científicos e tecnológicos dos jovens trabalhadores ribeirinhos da pesca.

Note-se ainda que fizeram parte do corpus empírico da pesquisa as informações contidas em documentos, como o Projeto Político e Pedagógico (PPP) da CEPE, o marco legal para seu funcionamento dado pela Portaria $n^{\circ}$ 031/2010, o PPP da Escola Bosque que é a mantenedora da CEPE e dados contidos nos certificados e diplomas auferidos pelos seus concluintes em nível de ensino fundamental e médio. Foram também utilizadas as falas da gestora e de professores/as da escola, conseguidas em atividades de visita de campo na CEPE nos meses de outubro e novembro de 2017.

\section{A Casa Escola da Pesca: aspectos conjunturais}

A Casa Escola da Pesca (CEPE) faz parte do Sistema Municipal de Educação de Belém e vincula-se administrativamente à Fundação Centro de Referência em Educação Ambiental Escola Bosque Professor Eidorfe Moreira (FUNBOSQUE), sendo esta sua mantenedora. A FUNBOSQUE constituise como um órgão da administração indireta, com personalidade jurídica de direito público, sediada na Av. Nossa Senhora da Conceição, s/n, Bairro do São João do Outeiro, na Ilha de Caratateua, Distrito de Outeiro, Município de Belém, estado do Pará (Belém, 2017).

A CEPE foi legalmente institucionalizada em 2 de fevereiro de 2010, todavia a sua implantação de fato data de 17 de abril de 2008 a partir de um “... Convênio firmado entre essa Fundação $^{2}$ e a Federação dos Pescadores do Estado do Pará (FEPA)”. Seu objetivo é “... a formação de filhos de pescadores e trabalhadores da pesca na Região das Ilhas com propósito de reduzir a pobreza e melhorar a gestão dos recursos naturais do Município de Belém/Pará”. (Funbosque, 2010, p. 10). 
Figura 2: Casa Escola da Pesca e alunos do ensino fundamental.

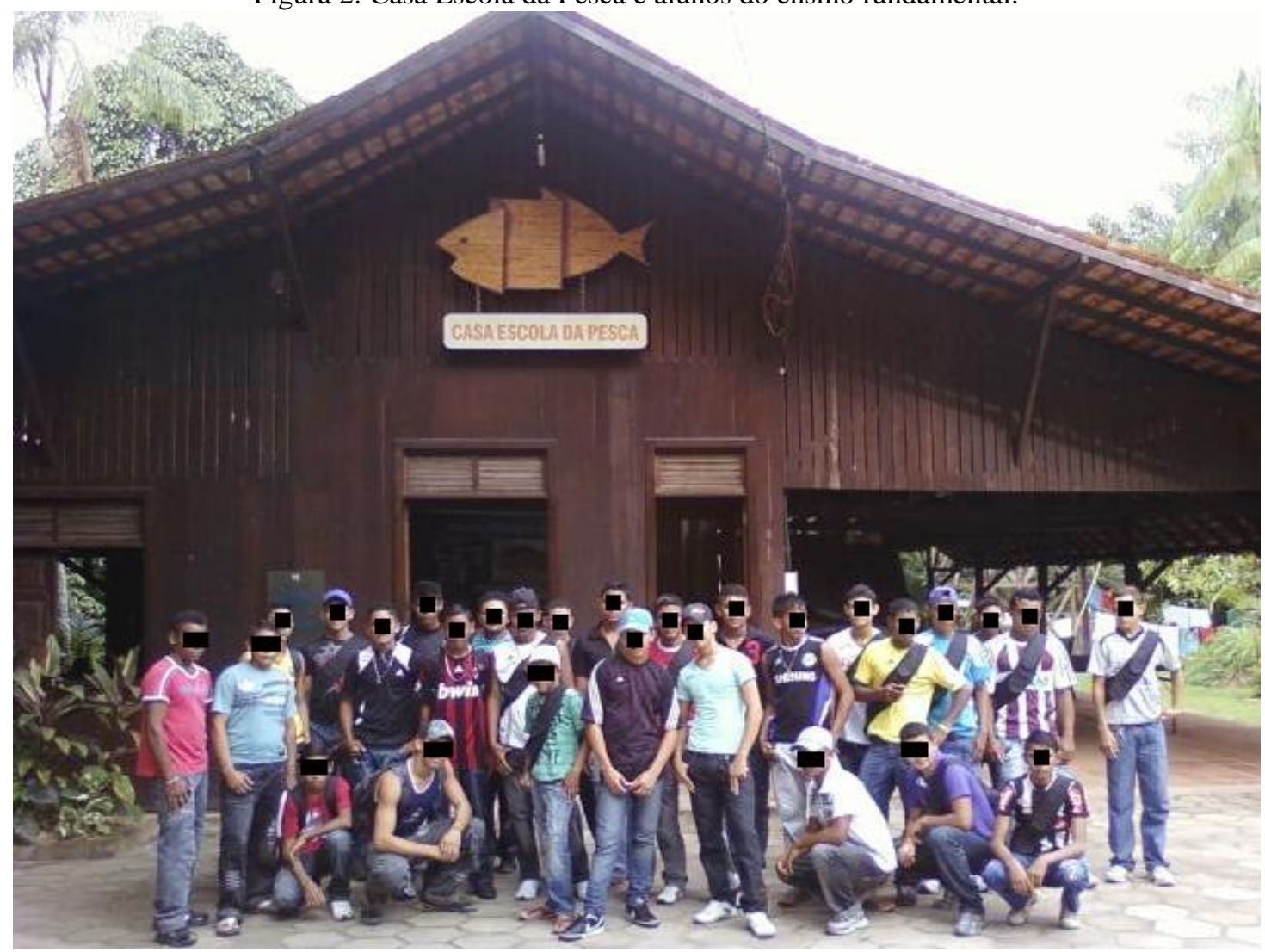

Fonte: Arquivo da CEPE, 2014.

O município de Belém apresenta áreas contínuas e insulares, estas perfazem um total de 39 (trinta e nove) ilhas (Silva, Santos \& Souza, 2016), dentre as quais a Ilha de Caratateua onde a CEPE está localizada na Rua Evandro Bona, Passagem São José, n 70, bairro Itaiteua, Distrito do Outeiro. Na Figura 3, a seguir, tem-se uma representação geral do Município de Belém. Nesta imagem é possível observar a parte continental e insular, em que se pode ver representada a ilha de Outeiro e um ponto em vermelho indicando o local onde está sediada a CAPE. Apesar de atender principalmente a uma demanda expressiva da ilha onde está instalada, a Escola possui discentes de outras comunidades ribeirinhas de Belém, tais como: Mosqueiro, Santa Cruz, Jutuba, Paquetá, Urubuoca, Jararaca e outras. 
Figura 3: Município de Belém e localização da CEPE.

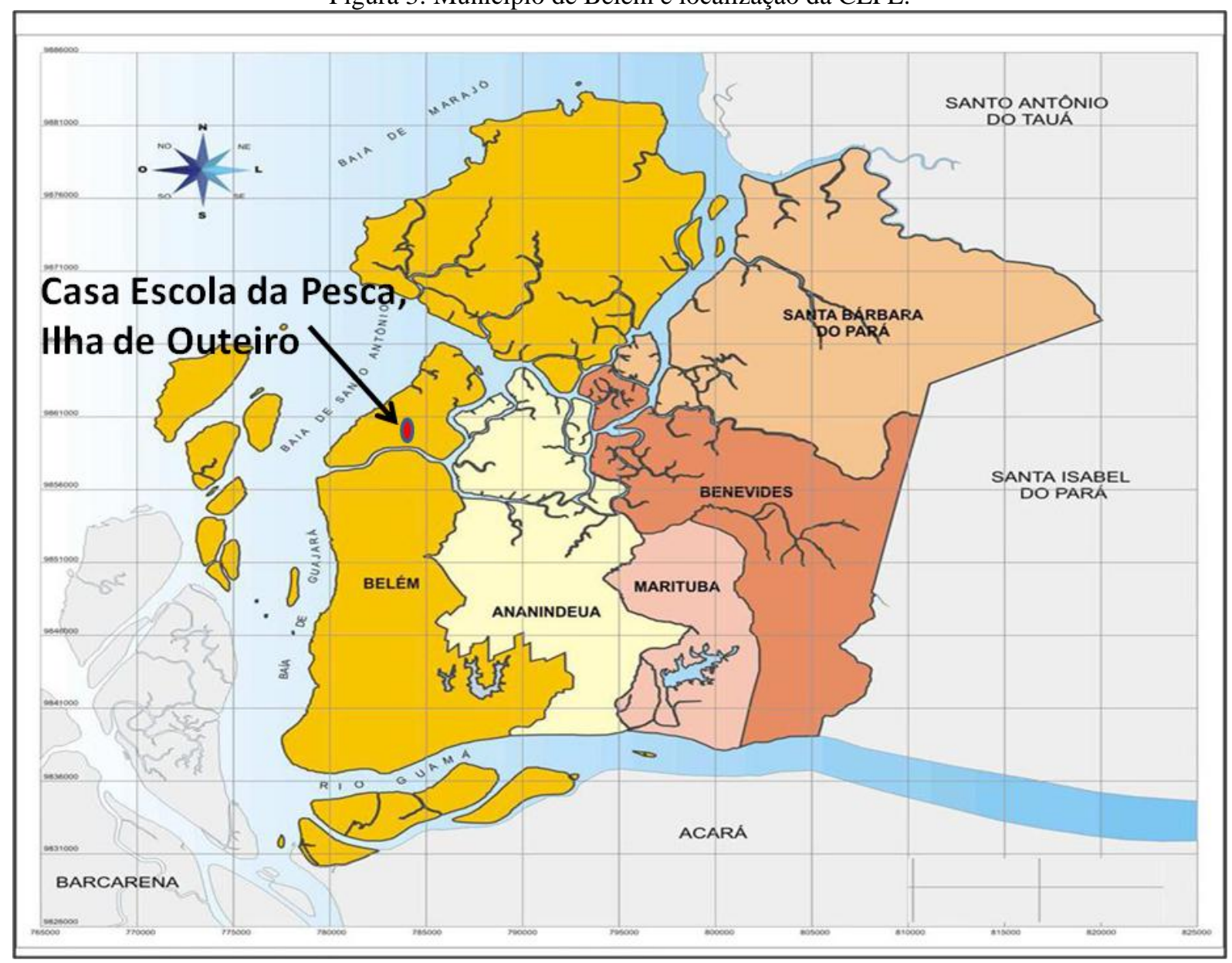

Fonte: Construdo pelos autores a partir de Silva, Santos e Souza (2016).

Conforme se observa em seu Projeto Político Pedagógico (Belém, 2013), a CEPE é uma Unidade de Ensino destinada a atender, preferencialmente, alunos/as ribeirinhos/as que, conforme posto pela LDBN, “... não tiveram acesso ou continuidade de estudos no ensino fundamental e médio na idade própria" (Brasil, 1996, Art. 37). Precisamente, a CEPE "caracteriza-se como unidade de ensino destinada a alunos na faixa etária de 15 a 24 anos para o Ensino Fundamental, e a partir de 18 anos para o ingresso no Ensino Médio, desde que tenham concluído o Ensino Fundamental”. (Belém, 2013, p. 27).

Enquanto espaço de escolarização na modalidade EJA, a CEPE propõe-se a conjugar a formação escolar em tempo integral com disciplinas propedêuticas e qualificação profissional. Assim, em dois anos de formação os/as discentes do Ensino Fundamental podem concluir seu percurso formativo com a certificação em Pesca e Aquicultura, ou em nível de Ensino Médio integrado com habilitação técnica em Recursos Pesqueiros. 
Como se observa nas imagens 4, 5, 6 e 7, a seguir, atualmente a CEPE vem enfrentando problemas de caráter infraestrutural, necessitando de reposição de materiais, consertos e pinturas prediais e melhorias em geral para seu funcionamento e acolhimento dos seus sujeitos educacionais. As imagens mostram beliches e colchões em péssimas condições de uso, banheiros com portas e louças danificadas e tantas outras coisas que denotam uma conjuntura atual da precariedade da Escola.

Figuras: 4, 5, 6 e 7: Imagens que denotam um pouco da realidade infraestrutural enfrentada na Casa Escola da
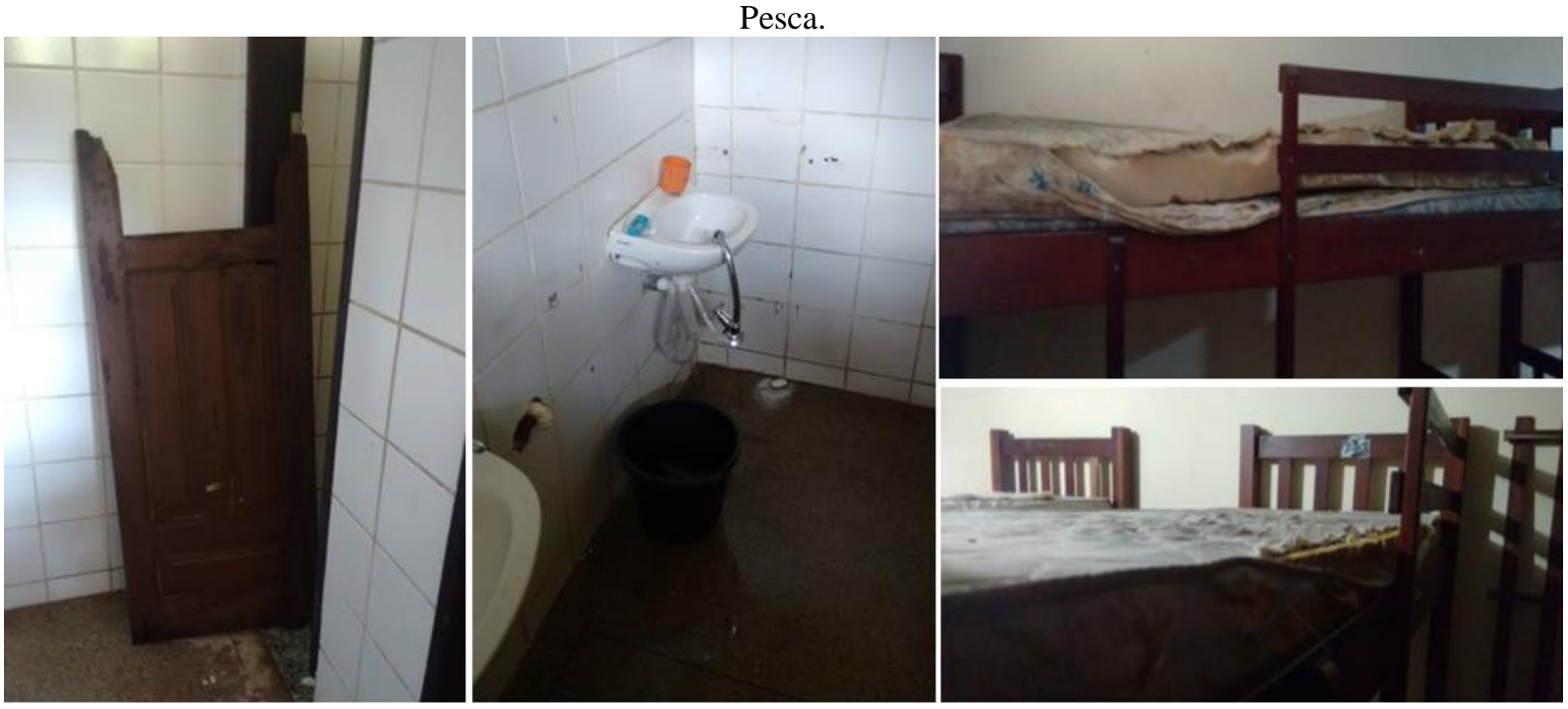

Fonte: José Bittencourt da Silva (2018).

Atualmente, a gestão escolar da CEPE liga-se ao grupo instalado no poder governamental local. Realmente, como não há eleição para a escolha dos gestores a direção da escola depende da indicação do próprio prefeito municipal de Belém. Por isso, mudam-se os prefeitos, mudam-se os dirigentes da escola e, consequentemente, as percepções e práticas pedagógicas formativas concernentes ao grupo no poder. Deste modo, a escola poderá ter um direcionamento conservador, neoliberal ou crítico e transformador dependendo do jogo político que se estabelece fora dos marcos institucionais da CEPE.

O Projeto Político Pedagógico (PPP) pode ser considerado como um dos mais relevantes documentos de gestão, constituindo-se em um excelente indicador da proposta administrativa e formativa de uma escola. Ele indica certas intencionalidades acerca do percurso formativo de seus educandos/as e expressa as possíveis relações que devem ser estabelecidas entre os diferentes sujeitos educacionais escolares. O PPP traz consigo 
uma proposta de escola no sentido mais global do termo, inclusive demonstra as possíveis interfaces a serem estabelecidas com o mundo social extramuros.

O projeto político-pedagógico tem a ver com a organização do trabalho pedagógico em dois níveis: como organização de toda a escola e como organização da sala de aula, incluindo sua relação com o contexto social imediato, procurando preservar a visão de totalidade. Nesta caminhada será importante ressaltar que o projeto político-pedagógico busca a organização do trabalho pedagógico da escola na sua globalidade. (Veiga, 2002, p. 3).

O atual PPP da CEPE foi construído e publicizado em 2013. Sua proposta pedagógica assenta-se na metodologia da Pedagogia da Alternância, a qual pressupõe dois tempos/espaços formativos diferentes e conjugados entre si. É a chamada pedagogia da alternância que se constitui como uma proposta pedagógica do Movimento Brasileiro por uma Educação do Campo surgido nas décadas de 1980/90 no âmbito das lutas do Movimento Sem Terra (MST).

A formação por alternância no campo brasileiro foi inaugurada pela Escola Família Agrícola (EFA) para atender especialmente aos filhos dos agricultores. Os movimentos sociais do campo, ao constatar as demandas dos jovens e adultos para continuarem seus processos formativos por meio da educação escolar, buscam, nesta forma de organização pedagógica, uma possibilidade de elevação da escolaridade dos jovens e adultos do campo brasileiro, especialmente com a conquista do Pronera, em 1998. A partir desta data, contabilizam-se inúmeros camponeses que puderam completar sua trajetória na educação escolar por meio da EJA/Pronera. ${ }^{3}$ (Araújo, 2012, p. 257).

O objetivo maior da pedagogia da alternância é a possibilidade de unir teoria e prática no contexto da formação discente, principalmente daqueles residentes em meio não urbano cujo desenvolvimento integral configura-se como a grande utopia educacional escolar, uma vez que esta metodologia pretende contemplar as múltiplas dimensões da condição dos sujeitos aprendentes, ou seja, seus aspectos econômicos, sociais, políticos e ambientais com rebatimentos diretos na sua vida comunitária local (Estevam, 2001).

Um aspecto muito marcante no PPP da CEPE é a ideia de que a escola deverá contribuir com o desenvolvimento da região ribeirinha. De fato, a palavra desenvolvimento aprece 44 vezes neste documento e está sempre relacionada a processos de melhoria pessoal ou coletivo de seus educandos/as. Não é raro encontrar no PPP expressões do tipo “... a necessidade da educação ser vista como um conjunto de elementos importantes ao desenvolvimento intelectual, social e integral do educando". (Belém, 2017, p. 11). Ou mesmo, 
As ações educativas irão considerar todas as possibilidades para desenvolver as atividades econômicas e estratégicas para o desenvolvimento social, cultural da região, e ainda viabilizar formação profissional para alavancar 0 desenvolvimento das comunidades ribeirinhas em nível regional, e para isso serão utilizados os recursos pesqueiros para geração de trabalho e renda. (ibidem, p. 12).

Escolarização, profissionalização e desenvolvimento: um enfoque junto a egressos da CEPE na Ilha de Cotijuba

Como demonstrado na Figura 1 acima, a ilha de Cotijuba, "trilha dourada" para os Tupinambá (Fernandes; Fernandes, 2016), faz parte do território municipal de Belém e integra o Distrito Administrativo de Outeiro (Belém, 1994). Com acesso apenas por via fluvial a ilha apresenta uma paisagem natural de mata e praia amazônicas. O lugar tornou um atrativo para o turismo de contemplação da natureza, o qual vem se constituindo na principal atividade econômica no local, em que pese haver em Cotijuba uma produção pesqueira artesanal importante e uma agricultura familiar que garante aos moradores uma fonte de alimento e renda (Silva, 2014).
$\mathrm{Na}$ ilha pode-se observar a existência física de uma agência administrativa da Prefeitura de Belém, um pequeno posto de saúde, unidades pedagógicas de ensino fundamental, igrejas católica e evangélica, pousadas, hotéis e bares. Porém, Cotijuba carece de alguns serviços públicos, como abastecimento de água potável (a água consumida pelos moradores é proveniente de poços), saneamento básico, recolhimento regular de resíduos sólidos, pavimentação de ruas e energia elétrica (na ilha a eletricidade advém de geradores que funcionam a óleo diesel).

É nessa ilha que moram os egressos da Casa Escola da Pesca que foram selecionados para as entrevistas e aplicação de questionários. Eles são jovens adultos na faixa etária entre 22 a 30 anos de idade e concluíram a educação escolar básica na CEPE no ano de 2015. Do ponto de vista formal, esses ex-alunos estão com os dois cerificados oferecidos pela Escola, ou seja, uma certificação em nível fundamental em Pesca e Aquicultura e outra em nível médio, com habilitação técnica em Recursos Pesqueiros (Figuras 8, 9, 10 e 11). 
Figuras 8 e 9: anverso e verso do diploma de conclusão do ensino médio com formação Técnica em Recursos Pesqueiros.

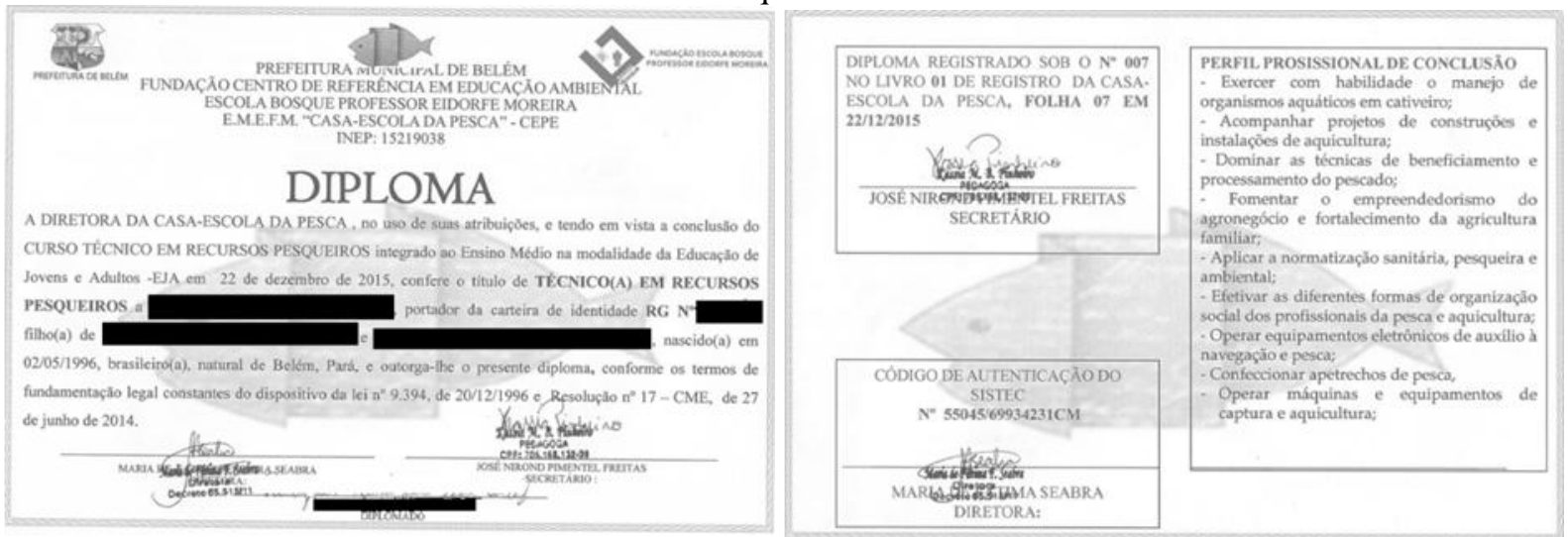

Fonte: dado da pesquisa de campo, 2018.

Figuras 10 e 11: anverso e verso do diploma em nível fundamental e com formação inicial em Pesca e Aquicultura.
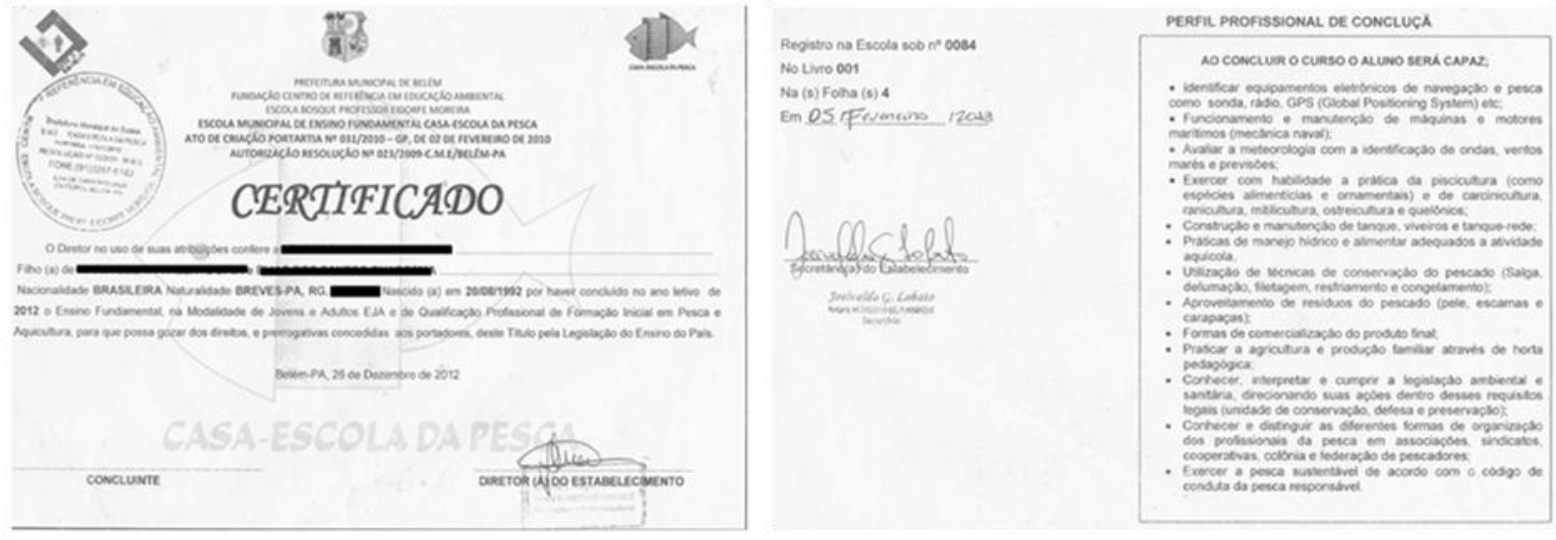

Fonte: dado da pesquisa de campo, 2018.

O ensino de EJA na CEPE também deveria edificar em seus discentes um desenvolvimento educacional suscetível de dar condições para seus egressos cursarem o nível superior (Belém, 2013). Contudo, o que se observou no período em que as entrevistas foram realizadas, foi que nenhum dos egressos ouvidos havia cursado ou estava cursando o nível superior de ensino ou participado de cursos de aperfeiçoamento na área da pesca. Apenas um egresso afirmou ter participado de um curso na Capitania dos Portos voltado à regularização dos condutores de pequenas embarcações.

Para além dessa expressão fenomênica observada in loco, pode-se compreender essa realidade como reveladora de estruturas que se repete em outros espaços educacionais escolares em escala nacional. Para Frigotto (2009) essa situação não é uma aberração dos sistemas educacionais que a escola poderia facilmente resolver. $\mathrm{Na}$ verdade, essa 
situação precária da educação de alunos da EJA/profissionalizante revela o modo como o capitalismo dependente se desenvolve de maneira desigual e combinada.

O Brasil seria uma composição de uma pequena Bélgica rica, moderna, e uma Índia atrasada, semianalfabeta, com valores tradicionais e com um enorme contingente de trabalhadores na informalidade. A parte Índia seria responsável pelo atraso, subdesenvolvimento e que impediria de nos tornarmos um país de capitalismo avançado. Ao contrário, o pensamento social crítico nos mostra que se trata de uma construção social que define a forma específica de nosso capitalismo dependente e subordinado. Uma sociedade cuja opção de desenvolvimento desigual e combinado pressupõe o analfabetismo, a escola dual com uma educação empobrecida para as massas, a informalidade e a desigualdade. (Frigotto, 2009, p. 74).

Do ponto de vista laboral todos estavam na informalidade, trabalhando sem carteira assinada como prestadores de serviços variados, em geral como condutores de veículos automotores pertencentes a pequenos comerciantes locais. Precisamente, os egressos da CEPE na ilha de Cotijuba têm sua principal fonte de renda ligada ao turismo, como motoristas de moto, charretes, motorretes (uma espécie "hibrida" de moto e charrete) levando os visitantes para as áreas turísticas mais requisitadas, como a Praia do Farol (Figura 12) ou as ruínas do Educandário Nogueira de Faria (Figura 13). Também desenvolvem atividades na construção civil, extrativismo do açaí, como vendedores ambulantes ou como trabalhadores em lanchonetes de quiosques e barracas na beira-rio.

Isso resulta de uma proposta de educação profissionalizante baseada na ideologia do desenvolvimento capitalista, que de acordo com Singer (2004) se efetiva a partir da lógica do capital, ou seja, determinado pelos ditames do mercado, da competição, do individualismo etc. $\mathrm{Na}$ realidade, a escola está reproduzindo na vida prática de seus egressos

O desenvolvimento explorador e espoliativo do capitalismo, a massificação das relações sociais, o descompasso entre o alto desenvolvimento tecnológico e a miséria social de milhões de pessoas, as frustrações com os resultados do consumo insaciável de bens e produtos, o desrespeito à dignidade humana de categorias sociais tratadas como peças ou engrenagens de uma máquina, o desencanto com a destruição gerada pela febre de lucro capitalista etc. (Gohn, 1992, p. 1516).

Com essa perspectiva educacional, a CEPE acaba cerceando do direito à educação emancipatória e promovendo um percurso educativo voltado ao domínio das habilidades e competências exigidas pelo mercado, oferecendo aos educandos uma formação profissional e de conhecimentos 
elementares de leitura, escrita, contas e noções primárias de ciências para a empregabilidade em trabalhos precarizados (Arroyo, 2012).

Pela própria característica da escola, isto é, um espaço educativo e formativo de populações ribeirinhas, o que se espera realmente da CEPE é uma formação a mais completa possível, uma educação que objetive plasmar nas pessoas $\mathrm{o}$ desenvolvimento de suas múltiplas dimensões físicas, intelectuais, afetivas ou estéticas. Por isso a sua proposta de integralidade educativa (Belém, 2013) pressupõe uma formação científica, artística, literária, filosófica, enfim, de tudo aquilo que a humanidade produziu de melhor em seu devir histórico (Libâneo, 2018).

Figuras 12 e 13: Praia do Farol e ruínas do Educandário Nogueira de Faria, Ilha de Cotijuba.

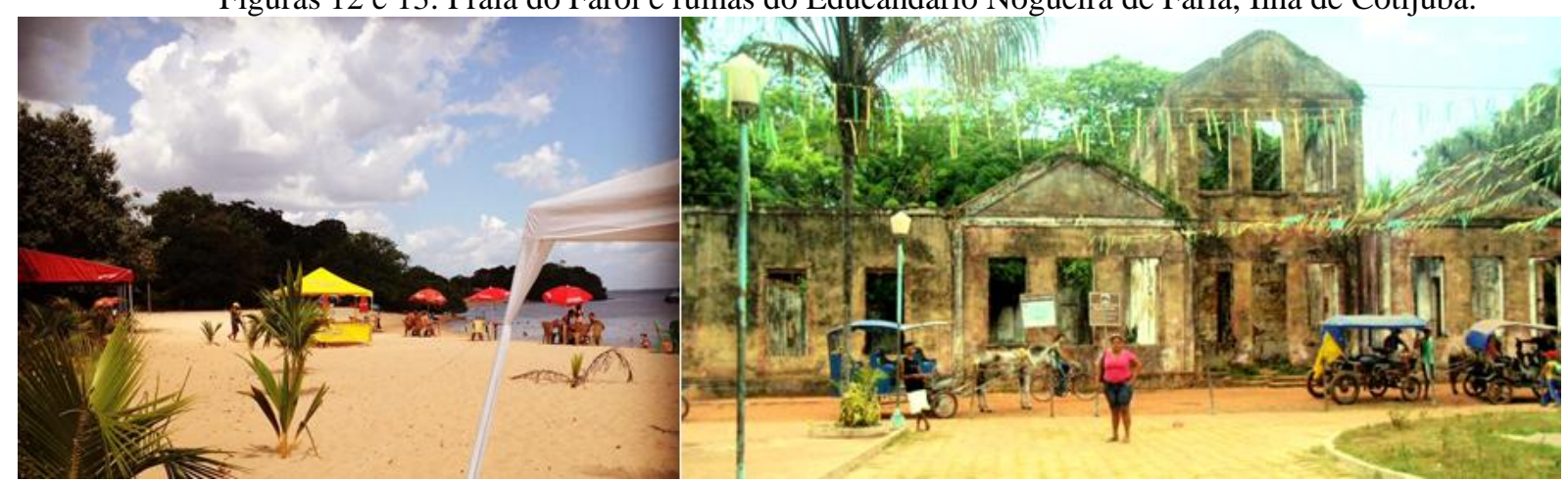

Fonte: Imagem capturada em meio virtual (A Ilha, 2018).

Aqui eu vivo de bico. Pra ganhar a vida eu faço de tudo. Eu capino, trabalho de ajudante de pedreiro, trabalho na motorrete, na charrete levando as pessoas pras praias mais longe ... (entrevistado 1).

Eu trabalho na motorrete e também no período da safra eu ajudo a minha família que tem açaizal aqui perto. Eu tenho um sonho de conseguir um bom emprego, mas pra isso eu acho que seria melhor se eu fosse um engenheiro de pesca, mas eu acho que esse sonho tá muito difícil. Porque precisa de dinheiro, aqui tudo é muito difícil ... (entrevistado 2).

$\mathrm{Eu}$ até queria trabalhar com a pesca, mas tem que ter dinheiro pra comprar os materiais. Eu queria trabalhar na marinha mercante pra conseguir dinheiro pra iniciar um projeto na área da pesca aqui. Acho que se eu tivesse uns três mil reais eu conseguia iniciar o meu projeto. Eu queria continuar estudando, fazer uma universidade, mas não tenho incentivo, nem na minha família nem dos meus amigos (entrevistado 3).

Eu queria ter um trabalho fixo que me desse segurança pra mim e pra minha família. Eu fui agora em novembro na Amase ${ }^{4}$, eu fui pela Casa Escola da Pesca. Eu fiz uma prova lá, mas até agora não me falaram nada. Aí eu fiquei sabendo de uma outra empresa de pesca no Outeiro, mas eu não fui lá, porque eu fiquei sabendo que eles iam me dar emprego por três meses, aí depois desse período eles iam ver se iam me contratar. Mas eu não ia receber nada 
nesses três meses. Eu não quis ir lá. $\mathrm{Eu}$ tô trabalhando hoje com motorrete, mas no momento eu tô parado porque eu tive um acidente. Em me queimei as pernas com gasolina em um acidente com a motorrete. $\mathrm{Eu}$ queria continuar estudando, mas pra isso é preciso de dinheiro. Só eu, meu pai e minha mãe que mais consegue dinheiro pra gente se sustentar na minha casa. Então isso é difícil. Porque se eu for estudar aí a coisa vai ficar mais difícil pra minha família (entrevistado 4).

O nosso desenvolvimento aqui ainda não conseguimos. Porque nossa família é de baixa renda, eu ajudo meu pai na construção civil, no turismo levando as pessoas pras praias do Farol, praias da Saudade, praias do Amor, praia do Vai Quem Quer ... (entrevistado 5).

Eu nasci em Belém e a minha vó me pegou pra criar. Eu vim morar aqui em Cotijuba, eu gosto muito de morar aqui. Às vezes eu vou pra Belém e fico um tempo por lá, às vezes eu fico aqui. Eu trabalho por aqui mesmo, ajudo minha família, faço uns bicos, faço transporte de aluno ... e assim a gente vai levando (entrevistado 6).

No anverso do diploma de conclusão do ensino médio (Figura 10 acima), estipula-se que o concluinte deverá apresentar saberes e competências quanto à "confecção de apetrechos de pesca e outros". No certificado de ensino fundamental (Figura 12 acima) e no PPP da escola (Belém, 2013, p. 20) aponta-se que o egresso deverá possuir expertise quanto ao exercício da "pesca sustentável de acordo com o código de conduta da pesca responsável". Ao ser indagado sobre esses saberes e conhecimentos sobre a pesca artesanal, os entrevistados 4 e 6 afirmaram que:

Na Casa Escola da Pesca nós tínhamos mais aula teórica do que prática. Por exemplo, nós íamos ter uma formação pra construir uma rede pesca. Aí o professor dava uma aula teórica, só no data show. Mas se o senhor pedir pra mim fazer uma rede de pesca, uma tarrafa, um espinhel, um matapi eu não sei fazer. Porque nós não tivemos prática dessas coisas. O que eu posso dizer que tenho um pouco mais de conhecimento é sobre a criação de peixe em tanque, principalmente porque eu estagiei na UFRA ${ }^{5}$. Mas mesmo assim eu preciso de mais formação hoje, porque nós não praticamos depois que a gente sai da escola e a gente vai esquecendo (entrevistado 4).

Nós estudamos todas essas matérias, matemática, história, sociologia ... e também matérias sobre a pesca, mas tudo muito teórico. Se o professor fosse falar sobre o tamanho da malha, os tipos de peixe, os tipos de maré, essas coisas, era tudo de boca. Não tinha nada de prática (entrevistado 6).

A ilha apresenta certa organização social bastante interessante do ponto de vista formal. De fato, existem em Cotijuba a Associação dos Produtores da Ilha de Cotijuba (APIC), a Associação dos Moradores da Ilha de Cotijuba e Ilhas Adjacentes (AMICIA), Movimento de Mulheres das Ilhas de Belém (MMIB), Cooperativa dos Charreteiros da Ilha de Cotijuba e outras. Tudo isso já seria um input a ser considerado como capaz de 
gerar as condições objetivas para um desenvolvimento comunitário local, baseado nos princípios do desenvolvimento solidário.

Apesar disso nenhum dos egressos disse fazer parte de alguma colônia de pescadores, associação ou cooperativa de trabalhadores voltada à pesca ou aquicultura. Também não são filiados a nenhum partido político e apresentam certa rejeição quanto a essa esfera da vida humana. De todos os entrevistados, apenas um disse estar associado à Cooperativa dos Charreteiros da Ilha de Cotijuba, mas não informou as garantias que ele possui enquanto cooperado. Sabe apenas que essa é uma condição para que possa desempenhar sua atividade de charreteiro com maior segurança.

Quadro 1: Participação dos egressos da CEPE em organização coletiva na ilha de Cotijuba.

\begin{tabular}{|c|c|c|}
\hline Identificação & $\begin{array}{c}\text { N. de organização } \\
\text { econômica ou social que } \\
\text { participa }\end{array}$ & Identificação da organização que participa \\
\hline Entrevistado 1 & 0 & \\
\hline Entrevistado 2 & 0 & Cooperativa dos Charreteiros da Ilha de Cotijuba \\
\hline Entrevistado 3 & 1 & \\
\hline Entrevistado 4 & 0 & \\
\hline Entrevistado 5 & 0 & \\
\hline Entrevistado 6 & 0 & \\
\hline
\end{tabular}

Fonte: pesquisa de campo (2018).

Ao serem indagados sobre a questão do associativismo enquanto aprendizado no contexto de sua formação, todos os egressos se mostraram sem nenhuma base conceitual ou prática acerca deste assunto.

Sobre as cooperativas nós tivemos muito pouco estudo sobre isso. Eu nem lembro muito bem sobre isso. Foi só no ensino médio que nós vimos isso muito rápido. Eu não me lembro de muita coisa sobre isso. $\mathrm{O}$ que eu me lembro mais ou menos é que as cooperativas têm que ter mais pessoas pra funcionar e a associação não precisa de muita gente. Eu não lembro muito bem, praticamente não sei nada. Era o nosso professor de pesca que falava pra nós sobre isso (entrevistado 4).
Efetivamente, o que se observou em campo foi a precarização do trabalho dos egressos, refletida principalmente na insegurança jurídica de suas relações laborais. De fato, eles apresentam remuneração aviltante, direitos trabalhistas inexistentes e nenhuma garantia de assistência previdenciária. Por outro lado, os egressos não possuem condições monetárias iniciais para o tão propalado empreendedorismo individual (Belém, 2013), muito menos crédito para a compra dos materiais necessários às viagens para alto mar, tampouco conseguem comprar os instrumentos de captura do pescado, 
logística para o armazenamento, transporte e comercialização de peixes em mercados locais ou alhures.

A alternativa seria a constituição de empresas cooperadas, o que exigiria, além de capital e crédito, certo acumulado de valores de confiança e solidariedade mútua, capacidade de formação de redes de cooperação, mecanismos de sanção e regras de comportamento que podem melhorar as ações coletivas (Putnam, 1996). Visto como um bem de todos os pertencentes à dada comunidade, estes valores coletivos são gerados historicamente no contexto de práticas organizativas horizontais (sindicatos, cooperativas, associações, clubes etc.), nos quais se estabelecem relações face a face que melhoram a confiança entre as pessoas. Quanto maior o tempo despendido na participação organizativa, ou seja, em reuniões, deliberações, encontros, tarefas para a resolução de questões comunitárias etc., mais os grupos se fortalecem em termos de confiança, solidariedade, reconhecimento mútuo, autoestima e interferindo positivação nas ações coletivas.

É neste sentido que as vivências cotidianas nas organizações sociais, políticas e econômicas são fundamentais no processo de construção de laços societárias que contribuam para as ações coletivas necessárias ao desenvolvimento local. Como não há um habitus organizacional, os egressos só conseguem pensar em empreendimentos individuais, nos mesmos moldes das relações sociais patronais das grandes empresas capitalistas pesqueiras, e acabam ficando presos a sonhos cada vez mais distantes de sua efetivação. Note-se que habitus aqui deve ser entendido como "princípio gerador de nossas práticas, de nossas ações no mundo, fundamento da regularidade de nossas condutas”. (Araújo, Alves \& Cruz, 2009, p. 38). Para Bourdieu (1983) o Habitus constitui-se na disposição que as pessoas individualmente possuem em relação a determinadas estruturas sociais que são introjetadas de maneira consciente ou inconscientemente, as quais condicionam seus sentimentos, visões sociais de mundo, suas ações coletivas dentro dos campos sociais dos quais as pessoas fazem parte.

Conforme posto por Gohn (1992, 2011), as organizações e os Movimentos Sociais são, por princípio, educadores coletivos da sociedade, entendida a educação como um componente da cultura (Brandão, 2006), ou seja, parte fundamental do processo de hominização dos indivíduos na coletividade.

Para nós, a educação não se resume à educação escolar, realizada na escola propriamente dita. Há aprendizagens e produção de saberes em outros 
espaços ... Um dos exemplos de outros espaços educativos é a participação social em movimentos e ações coletivas, o que gera aprendizagens e saberes. Há um caráter educativo nas práticas que se desenrolam no ato de participar, tanto para os membros da sociedade civil, como para a sociedade mais geral, e também para os órgãos públicos envolvidos - quando há negociações, diálogos ou confrontos. (Gohn, 2011, p. 333).

Quanto ao caráter educativo dos movimentos sociais, a autora afirma de maneira conclusiva que eles são espaços férteis para a inovação e fontes geradoras de saberes. Por isso, seria de grande valia que a CEPE colocasse o cooperativismo ou associativismo como componente estruturante do percurso formativo de seus educandos, efetivando aquilo que está colocado no anverso do diploma de conclusão do ensino médio da CEPE (Figura 10, acima). Nele pode-se ler que o perfil profissional do concluinte desse nível de ensino, deveria garantir ao egresso saberes e competências quanto às diferentes formas de organização social dos profissionais da pesca.

No concernente ao ensino fundamental, vale destacar que os alunos concluintes deveriam estar aptos, dentre outras coisas, a “... conhecer e distinguir as diferentes formas de organização dos profissionais da pesca, em associações, sindicatos, cooperativas, colônia e federação de pescadores". (Belém, 2013, p.
20; Figura 12, acima). Essa é uma realidade que precisa ser construída e a CEPE não pode se eximir de seu papel de edificadora dessa base associativa para seus/suas alunos/as. Caso contrário essa realidade precária dos egressos, moradores de Cotijuba, será replicada para as outras comunidades ribeirinhas de Belém assistidas pela Escola.

\section{Conclusão}

A CEPE é uma escola pública municipal na modalidade EJA profissionalizante correspondente aos níveis fundamental e/ou médio, desenvolvendo suas atividades educacionais na ilha de Outeiro (Caratateua), Belém, Pará desde 2008. Seu público alvo são filhos e filhas de pescadores/as e trabalhadores/as da pesca das áreas ribeirinhas do município de Belém. Do ponto de vista formal, seus egressos da EJA/ensino médio podem continuar estudando em nível superior e/ou desenvolver atividades pesqueiras em suas comunidades.

No PPP desta escola pode-se observar que a palavra desenvolvimento constitui-se como uma categoria fundante quanto aos seus objetivos educacionais. De fato, a palavra desenvolvimento aparece grafada 44 vezes, sempre associada a aspectos individuais e coletivos de 
melhoria socioeconômica ou culturalambiental de seus/suas educandos/as. Para tanto, propõe-se a implementação de um percurso educacional integrando a formação básica com a profissional, tendo a atividade da pesca como referência laboral. Para a efetivação formativa dos/as discentes, a CEPE se propõe a contemplar integrativamente os tempos escolares com os saberes e práticas locais comunitárias com base na Pedagogia da Alternância.

A se tomar a escola isoladamente, é possível afirmar que a CEPE apresenta totais e objetivas possibilidades para a realização de uma educação de qualidade e inovadora para os filhos e filhas dos/as trabalhadores/as das áreas insulares de Belém, não apenas no que concerne a sua autonomia pedagógica, como também em relação ao compromisso e qualidade formativa de seus sujeitos educacionais.

Todavia, o que se observou com a pesquisa de campo junto a egressos da CEPE foi que há um hiato muito grande entre os objetivos de desenvolvimento local, proposto pelo PPP desta escola, e a realidade vivida por seus egressos. $\mathrm{O}$ caso tomado como referência para as análises, a ilha de Cotijuba, constituiu-se uma amostra da atual situação vivida pelos egressos da CEPE, demonstrando que há realmente um fosso entre o dito e o percebido.
$\mathrm{Na}$ prática o que se viu foi a precarização do trabalho dos egressos, com insegurança jurídica em suas relações laborais, remuneração aviltante, direitos trabalhistas negados, nenhuma garantia de assistência previdenciária e distantes daquilo que estudaram durante anos como alunos da Casa Escola da Pesca. Precisamente, os ex-alunos da CEPE trabalham como condutores de charretes, de motocicletas e "motorretes", na construção civil, limpeza de árias residenciais, vendedores ambulantes e até mesmo como garçons em barras e quiosques de bebidas e comidas nas áreas de praia.

Os egressos não conseguem acessar o nível superior de ensino, nem tampouco conseguem as condições financeiras iniciais para empreender individual ou coletivamente negócios empresariais. Por isso têm na prestação informal de serviços a única possibilidade de garantir renda para seu sustento e de suas famílias. Como se não bastasse tudo isso, eles apresentaram baixíssima capacidade organizativa e, por conseguinte, de formação de rede de confiança e solidariedade para além da realidade doméstica familiar.

A escola não pode se furtar a sua condição de espaço de aprendizagem e, portanto, precisa ensinar aos seus/suas educandos/as o modo como estão 
inseridos/as nas estruturas sociais, políticos e econômicos de uma formação social determinada (a sociedade capitalista). Os/as alunos/as precisam entender criticamente a maneira como esta sociedade funciona, suas relações sociais de produção e racionalidade acumulativa de riqueza dominante e, assim, poder observar a realidade conjuntural concreta dos ribeirinhos amazônidas em seu conjunto e, em particular, a belenense.

A CEPE certamente não resolverá os problemas relativos ao desenvolvimento socioeconômico e educacional de seus egressos, tampouco das comunidades ribeirinhas assistidas. Há outras variáveis que precisam ser colocadas neste contexto. Todavia, a escola não pode negligenciar $\quad 0 \quad$ aprendizado problematizador, crítico e criativo, desvelando a realidade social de seus/suas educandos/as, inclusive mostrando que o desenvolvimento é uma visão de mundo, a qual pode ser capitalista ou solidária, e neste sentido pode ser mais individualistas ou associativista. Essas informações são essenciais para a análise qualificada dos problemas locais e possíveis proposições e alternativas ao desenvolvimento comunitário ribeirinho, para que seja socialmente justo e ambientalmente sustentável.

\section{Referências}

A Ilha de Cotijuba. (2018). Recuperado de http://www.vilacotijuba.com.br/p/sobre.ht $\underline{\mathrm{ml}}$

Araújo, F. M. B., Alves, E. M., \& Cruz, M. P. (2009). Algumas reflexões em torno dos conceitos de campo e de habitus na obra de Pierre Bourdieu. Revista Perspectivas da Ciência e Tecnologia, 1(1), 31-40. Recuperado de: http://revistascientificas.ifrj.edu.br:8080/re vista/index.php/revistapct/article/viewFile/ $\underline{14 / 14}$

Araújo, M. N. R. (2012). Educação de jovens e adultos (EJA). In Caldart, R. S., et al. (Orgs.). Dicionário da Educação do Campo (pp. 252-259). Rio de Janeiro: Escola politécnica de saúde Joaquim Venâncio, Expressão Popular.

Arroyo, M. G. (2012). Tempos humanos de formação. In Caldart, R. S. et al. (Orgs.). Dicionário da Educação do Campo (pp. 735-742). Rio de Janeiro: Escola politécnica de saúde Joaquim Venâncio, Expressão Popular.

Belém (Município). (2017). Projeto Político Pedagógica da Escola Bosque. Belém: Secretaria Municipal de Educação, Fundação Centro de Referência em Educação Ambiental Escola Bosque Professor Eidorfe Moreira.

(2013). Projeto Político Pedagógica da Casa Escola da Pesca. Belém: Secretaria Municipal de Educação, Casa Escola da Pesca.

Belém. (1994). Lei $\mathrm{n}^{\circ} 7682$ de 05 de janeiro de 1994. Dispõe sobre a regionalização administrativa do município de Belém, delimitando os respectivos espaços territoriais dos distritos administrativos e dá outras providências. Diário Oficial do Município. 05 de janeiro de 1994. Recuperado de: http://cm- 
belem.jusbrasil.com.br/legislacao/583592/1 ei-7682-94

Bourdieu, P. (1983). Questões de sociologia. Rio de Janeiro: Marco Zero.

Brandão, C. R. (2006). O que é educação. $48^{\circ}$ Ed. São Paulo: Brasiliense (Coleção Primeiros Passos).

Brasil. (2000). Lei $n^{o} 9.985$ de 18 de Julho de 2000. Institui o Sistema Nacional de Unidades de Conservação da NaturezaSNUC. Brasília. Recuperado de: http://www.planalto.gov.br/ccivil_03/leis/L 9985.htm

Brasil. (1996). Lei $\mathrm{n}^{\circ}$ 9394, de 20 de dezembro de 1996. Estabelece as diretrizes e bases da educação nacional. DOU. Brasília, DF, 20 dez. 1996. Recuperado de: http://www.planalto.gov.br/ccivil_03/leis/1 9394.htm

Comissão Mundial sobre Meio Ambiente e Desenvolvimento (CMMAD). (1988). Nosso futuro comum. Rio de Janeiro: Fundação Getúlio Vargas.

Dicionários Porto Editora. (2018). Desenvolvimento. Recuperado de: https://www.infopedia.pt/dicionarios/lingu a-portuguesa/desenvolvimento

Dicionário Online de Português. (2018). Desenvolvimento. Recuperado de: https://www.dicio.com.br/desenvolvimento l

Estevam, D. O. (2001). Casa Familiar Rural: a formação com base na Pedagogia da Alternância. 2001. (Dissertação de Mestrado). Universidade Federal de Santa Catarina, Florianópolis. Recuperado de: https://repositorio.ufsc.br/xmlui/handle/12 $3456789 / 81745$ ? show $=$ full

Fernandes, A. P. C. S., \& Fernandes, A. S. (2016). A (in) acessibilidade nos transportes e as pessoas com deficiência da comunidade ribeirinha da Amazônia paraense. Revista Cocar, 10(19), 240-264.

Frigotto, G. (2009). Teoria e práxis e o antagonismo entre a formação politécnica e as relações sociais capitalistas. Trabalho, Educação e Saúde, 7, 67-82. Doi: http://dx.doi.org/10.1590/S198177462009000400004

Fundação Escola Bosque (FUNBOSQUE) (2010). Portaria $n^{o}$ 031/2010. Cria a Casa Escola da Pesca. DOM n ${ }^{\circ} 11.556$, de 05 Fev. Recuperado de: http://www.belem.pa.gov.br/diarioom/inde $\underline{x . j s f}$

Furtado, C. (1961). Desenvolvimento $e$ subdesenvolvimento. Rio de Janeiro: Fundo de Cultura.

Gohn, M. G. (1992). Movimentos Sociais e Educação. São Paulo: Cortez.

(2011). Movimentos sociais na contemporaneidade. Revista Brasileira de Educação, 16(47), 333-512. Recuperado de:

http://www.scielo.br/pdf/rbedu/v16n47/v1 $\underline{6 n 47 a 05 . p d f}$

Kosik, K. (1976). Dialética do Concreto. $5^{\text {a }}$ Ed. Rio de Janeiro: Paz e Terra.

Latouche, S. (2009). O desenvolvimento representa o problema e o não o remédio para a mundialização! In Brune, F. et al. (Orgs.). Desfazer o desenvolvimento para refazer o mundo. (Tradução de José Maria de Almeida). Vargem Grande Paulista-SP: Cidade Nova.

Layrargues, P. P., \& Lima, G. F. C. (2014). As macrotendências político-pedagógicas da educação ambiental brasileira. Ambiente e Sociedade, 1(71), 23-40. Recuperado de: http://www.scielo.br/scielo.php?script=sci arttext\&pid=S1414753X2014000100003\&lng=en\&nrm=iso 
Libâneo, J. C. (2018). Escola de tempo integral em questão: lugar de acolhimento social ou de ensino-aprendizagem?. Recuperado de: http://professor.pucgoias.edu.br/SiteDocent e/admin/arquivosUpload/5146/material/Va ldeniza\%20ESCOLA\%20DE\%20TEMPO \%20INTEGRAL\%2023.8.docx

Marialva, M. E. A. (2011). PRONERA: política pública na educação de assentados (as) da reforma agrária. 2011. (Dissertação de Mestrado). Universidade Estadual de Campinas, Campinas. Recuperado de: http://www.bibliotecadigital.unicamp.br/do cument $/$ code $=000847492$

Marx, K. (2008). Contribuição à crítica da Economia Política. (Tradução e Introdução de Florestan Fernandes). 2a . ed. São Paulo: Expressão Popular.

Oliveira, L. D. (2005). A Ideologia do Desenvolvimento Sustentável: notas para reflexão. Revista Tamoios, 2, 41-46.

Pires, A. P. (2010). Amostragem e pesquisa qualitativa: ensaio teórico e metodológico. In: Pupart, J. (et al.). A pesquisa qualitativa: enfoques epistemológicos e metodológicos (pp. 127153). $2^{\mathrm{a}}$ Ed. Petrópolis, RJ: Vozes (Coleção Sociologia).

Porto-Gonçalves, C. W. (2012). Ambiente (meio ambiente). In Caldart, R. S. (Org.). Dicionário da Educação do Campo (pp. 96-104). Rio de Janeiro, São Paulo: Escola Politécnica de Saúde Joaquim Venâncio, Expressão Popular.

Putnam, R. (1996). Comunidade $e$ democracia: a experiência da Itália moderna. Tradução de L. A. Monjardim. Rio de Janeiro: Fundação Getúlio Vargas.

Sachs, I. (1986). Ecodesenvolvimento: crescer sem destruir. São Paulo: Vértice.
Silva, C. E. M. (2012). Desenvolvimento sustentável. In Caldart, R. S. (Org.). Dicionário da Educação do Campo (pp. 206-211). Rio de Janeiro, São Paulo: Escola Politécnica de Saúde Joaquim Venâncio, Expressão Popular.

Silva, G. V. et al. (2014). Percepção ambiental na área de proteção ambiental na ilha de Cotijuba, Belém, Pará. Enciclopédia Biosfera, 10(18), 3977-3985.

Silva, J. B., Santos, J., \& Souza, N. S. D. (2016). Escola básica e comunidades ribeirinhas em Belém, Estado do Pará: Problemas e Perspectivas. In KLA Working Paper, 18, Kompetenznetz Lateinamerika - Ethnicity, Citizenship, Belonging; Recuperado de: http://www.kompetenzla.unikoeln.de/fileadmin/WP_Bittencourt.pdf

Silva, J. B. (2009). Populações do campo na Amazônia brasileira: desenvolvimento, capital social e o papel da educação. Revista Margens, 4(6), 39-54.

(2018). Inovação escolar $e$ escolas municipais de tempo integral em Belém do Pará: um estudo nas ilhas Mosqueiro e Caratateua. Edital n. 06/2017 - PROPESP/UFPA, de 10 de abril de 2017. Belém: Universidade Federal do Pará.

Singer, P. (2004). Desenvolvimento capitalista e desenvolvimento solidário. Estudos Avançados, 18(51). Doi: http://dx.doi.org/10.1590/S0103$\underline{40142004000200001}$

Souza, N. S. D. (2015). Na Belém Ribeirinha, a Juventude e o Direito à Escolarização com Educação Profissional: análise da experiência da Casa Escola da Pesca. (Tese de Doutorado). Universidade Federal do Pará, Belém. 
Veiga, I. P. A. (Org.). (2002). Projeto político-pedagógico da escola: uma construção possível. $14^{\mathrm{a}}$ Ed. Papirus.

${ }^{1}$ Expressão latina que significa por cabeça.

2 Fundação Centro de Referência em Educação Ambiental Escola Bosque Professor Eidorfe Moreira.

3 Programa Nacional de Educação na Reforma Agrária (PRONERA) foi criado em 1998, a partir da mobilização dos Movimentos Sociais, em particular do Movimento dos Trabalhadores Rurais Sem Terra - MST. Este programa tem como principal proposta alfabetizar e elevar o grau de escolaridade de jovens e adultos de projetos de assentamentos da reforma agrária. Sobre PRONERA ver Marialva (2011).

${ }^{4}$ A Amazônia Seoul Importação e Exportação Ltda (AMASE) é uma grande empresa voltada à pesca de crustáceos e moluscos em água salgada e água doce, com endereço na rua Manoel Barata, 1789, Icoaraci, Belém, Pará, Brasil.

${ }^{5}$ Universidade Federal Rural da Amazônia.

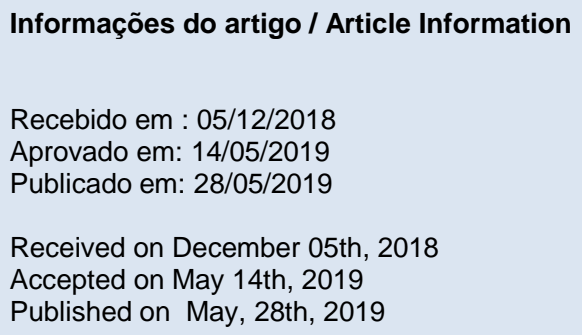

Contribuições no artigo: $O$ autor foi a responsável por todas as etapas e resultados da pesquisa, a saber: elaboração, análise e interpretação dos dados; escrita e revisão do conteúdo do manuscrito e; aprovação da versão final a ser publicada.

Author Contributions: The author was responsible for the designing, delineating, analyzing and interpreting the data, production of the manuscript, critical revision of the content and approval of the final version to be published.

Conflitos de interesse: $O$ autor declarou não haver nenhum conflito de interesse referente a este artigo.

Conflict of Interest: None reported.

Orcid

José Bittencourt da Silva

http://orcid.org/0000-0002-5393-1170

\section{Como citar este artigo / How to cite this article}

APA

Silva, J. B. (2019). Escolarização, profissionalização e desenvolvimento em escola do campo: o caso de egressos da CEPE na llha de Cotijuba, Belém, Pará. Rev. Bras. Educ. Camp., 4, e6247. DOI: http://dx.doi.org/10.20873/uft.rbec.e6247

ABNT

SILVA, J. B. Escolarização, profissionalização e desenvolvimento em escola do campo: o caso de egressos da CEPE na llha de Cotijuba, Belém, Pará. Rev. Bras. Educ. Camp., Tocantinópolis, v. 4, e6247, 2019. DOI: http://dx.doi.org/10.20873/uft.rbec.e6247 